\title{
EMPATI DAN PENGGUNAAN SITUS JEJARING SOSIAL SEBAGAI FAKTOR DALAM MEMBENTUK MORAL REMAJA
}

\author{
Selviana ${ }^{1}$ \\ Fakultas Psikologi \\ Universitas Persada Indonesia YAI \\ J1. Diponegoro No. 74, \\ Jakarta Pusat, 10430, Indonesia \\ 1e-mail: selviana.psikologi@gmail.com
}

\begin{abstract}
This study aimed to look at the effect of empathy and the use of social networking sites as factors to moral behavior of adolescents. The subjects of this study were 294 students of grade 10th and 11th years of a public high school at Bekasi. Results showed that empathy directly affects moral behavior, which means that when the level of empathy is improved, it can form morals into a better direction. Meanwhile, the use of social networking sites affects moral behavior directly, which means that when the use of social networking sites are used for positive things, it can shape moral and when used for negative purposes, it will be the opposite. The findings demonstrate empathy and the use of social networking sites in shaping moral.
\end{abstract}

Keywords: Adolescents; moral behavior; empathy; use of social networking sites.

Abstrak - Penelitian ini bertujuan untuk melihat besarnya pengaruh empati dan penggunaan situs jejaring sosial terhadap faktor-faktor pembentuk perilaku moral remaja. Partisipan dalam penelitian ini adalah 294 orang siswa SMA dan SMK kelas X dan XI sebuah sekolah di kawasan Bekasi. Hasil penelitian menunjukkan empati berpengaruh secara langsung terhadap perilaku moral dengan, yang berarti bahwa bila kadar empati atau kepedulian terhadap sesama semakin ditingkatkan, maka dapat membentuk moral remaja ke arah yang lebih baik. Sementara itu, penggunaan situs jejaring sosial memberikan pengaruh secara langsung terhadap moral remaja, yang berarti bahwa bila penggunaan situs jejaring sosial dipakai untuk hal-hal yang baik, maka dapat turut membentuk moral remaja ke arah yang lebih baik; dan bila dipakai untuk tujuan yang negatif, maka akan sebaliknya. Hasil ini menunjukkan betapa pentingnya empati dan penggunaan situs jejaring sosial dalam membentuk moral remaja masa kini.

Kata Kunci: Remaja; perilaku moral; empati; penggunaan situs jejaring sosial. 


\section{PENDAHULUAN}

Masa remaja merupakan masa transisi dari masa kanak-kanak menuju dewasa. Beberapa tokoh mengemukakan masa remaja sebagai "storm and stress" (badai dan tekanan), di mana pada periode ini remaja mengalami konflik dan kontradiksi yang tidak terelakkan sehingga banyak memengaruhi perilakunya (Gunarsa \& Gunarsa, 2012; Hurlock, 1999). Hal ini berkenaan dengan perilaku yang baik dan buruk, perilaku yang didasari pada nilai-nilai dan norma-norma yang berlaku secara umum atau disebut juga perilaku moral (Santrock, 2005). Proses pembentukan moral remaja dimulai di rumah, lingkungan sekitar dan khususnya sekolah. Melalui sekolah, remaja belajar berbagai ilmu pengetahuan sekaligus bersosialisasi. Terkait dengan hal tersebut, pendidikan mendapat perhatian khusus oleh pemerintah Indonesia, yaitu dengan dirumuskannya Undang-Undang RI No. 20 Tahun 2003 tentang Sistem Pendidikan Nasional Bab 2 Pasal 3 yang berbunyi:

Pendidikan nasional berfungsi untuk mengembangkan kemampuan, membentuk watak serta peradaban bangsa yang bermartabat dalam rangka mencerdaskan kehidupan bangsa, bertujuan untuk mengembangkan potensi peserta didik agar menjadi manusia yang beriman, bertakwa kepada Tuhan Yang Maha Esa, berakhlak mulia, sehat, berilmu, cakap, kreatif, mandiri dan menjadi warga negara yang demokratis serta bertanggung jawab.

Rumusan undang-undang di atas secara jelas menyatakan bahwa pendidikan mempunyai fungsi yang penting dalam membentuk peserta didik baik secara intelektual maupun perilaku. Namun dalam kenyataannya, masih banyak permasalahan yang terjadi di kalangan pelajar, khususnya remaja yang tergolong dalam kenakalan remaja. Gunarsa dan Gunarsa (2012) mengemukakan bahwa kenakalan remaja (juvenile delinquency) digolongkan menjadi dua. Pertama, kenakalan yang bersifat immoral atau tidak diatur dalam undang-undang pelanggaran hukum, seperti: berbohong, membolos, mencontek, melawan guru atau orangtua, berpakaian tidak pantas, bergaul dengan teman yang memberi pengaruh buruk, kabur dari rumah, dan sebagainya. Kedua, kenakalan yang bersifat melanggar hukum sesuai dengan undang-undang, seperti: penyalahgunaan narkoba, perjudian, pencurian, aborsi, penipuan, pembunuhan, dan lain-lain. Sementara itu, Santrock (2003) menyebutkan kenakalan remaja yang terkait dengan moral adalah pelanggaran status (status offenses) dan kenakalan remaja yang terkait dengan tindak kriminal atau pelanggaran hukum adalah pelanggaran indeks (index offenses). Dari pendapat tersebut, dapat dinyatakan bahwa kehidupan remaja rentan dengan berbagai permasalahan. 
Rentannya berbagai permasalahan ini juga didasari oleh pendapat Hall (dalam Santrock, 2003) yang mencetuskan istilah storm and stress (badai dan tekanan). Hall mengemukakan bahwa remaja sebagai masa goncangan yang ditandai dengan konflik dan perubahan suasana hati. Menurut Hall, dalam masa ini pikiran, perasaan, dan perilaku remaja berubah-ubah antara kesombongan dan kerendahan hati, baik dan godaan, kebahagiaan dan kesedihan. Pada suatu saat, remaja mungkin bersikap buruk terhadap kawan, pada saat yang lain remaja ingin berada sendirian pada suatu waktu, tetapi beberapa waktu kemudian mencari teman. Sementara itu, Barnet (dalam Gunarsa, 2009) mengungkapkan bahwa terdapat tiga elemen kunci pada masa badai dan tekanan yang terjadi pada remaja. Pertama, konflik dengan orangtua yang mencakup larangan-larangan, misalnya kesopanan dalam berpenampilan, kapan diperbolehkan untuk berpacaran, ke mana saja boleh bepergian, serta jam berapa harus sampai di rumah. Kedua, gangguan suasana hati seperti perasaan aneh atau perasaan tidak nyaman, khawatir, gugup, dan kurang diperhatikan. Ketiga, kecenderungan melakukan hal-hal yang berisiko, yakni perilaku-perilaku yang secara potensial dapat merugikan diri sendiri maupun orang lain misalnya menggunakan narkoba, melakukan hubungan seks di luar nikah, aborsi dan lain-lain.

Mengacu pada berbagai argumen di atas, maka dalam penelitian ini peneliti lebih tertarik untuk menyoroti mengenai remaja dari sisi perilaku yang didasari oleh nilai dan norma atau disebut juga perilaku moral, dengan pertimbangan bahwa remaja merupakan populasi tertentu dengan berbagai permasalahannya. Selain itu, permasalahan moral dapat ditangani dengan cara mendidik remaja menuju perilaku yang lebih baik, sedangkan masalah kriminal diselesaikan dengan jalur hukum dan juga remaja yang mengalami masalah moral dapat lebih terbuka dibandingkan remaja yang mengalami masalah tindak kriminal dikarenakan stigma masyarakat terhadap pelaku kejahatan. Terkait dengan hal tersebut, Santrock (2005) menyatakan bahwa perilaku moral berhubungan dengan peraturan-peraturan dan nilai-nilai mengenai apa yang harus dilakukan seseorang dalam interaksinya dengan orang lain. Hal ini mengacu pada perilaku seseorang yang didasari oleh peraturan-peraturan dan nilai-nilai tertentu dalam berhubungan dengan orang lain dan perilaku ini selanjutnya akan berdampak bagi kesejahteraan manusia. Dari pengertian ini dapat dikatakan bahwa remaja yang bermasalah perilaku moralnya adalah remaja yang melakukan hal-hal yang bertentangan dengan maksud di atas.

Permasalahan perilaku moral yang terjadi pada kalangan remaja tidak terjadi begitu saja. Dalam hal ini, terdapat faktor-faktor yang memengaruhi permasalahan tersebut. Berdasarkan berbagai sumber yang terkait dengan perilaku moral, maka faktor-faktor yang memengaruhinya, antara lain: identitas, kontrol diri, usia, jenis kelamin, harapan terhadap pendidikan dan nilai-nilai di sekolah, pengaruh orangtua, pengaruh teman sebaya, pengaruh media khususnya situs jejaring sosial, status sosial ekonomi, dan kualitas 
lingkungan sekitar tempat tinggal (Gunarsa \& Gunarsa, 2012; Jahja, 2011; Santrock, 2003). Sementara itu, beberapa tokoh dan peneliti terdahulu berpendapat bahwa faktor-faktor yang memengaruhi perilaku moral pada remaja adalah: pertimbangan moral, identitas moral, motivasi moral, religiusitas, nurani, empati, social capital, pola asuh, dan peran sosial (Borba, 2001; Budiningsih, 2008; Carlo \& Hardy, 2005; Cotton, 2012; Hardy, Rackham, \& Olsen, 2012; Sarwono, 2005; Vitell, dkk., 2009; Zubaidi, 2009).

Dalam penelitian ini peneliti memilih empati sebagai faktor internal dan penggunaan situs jejaring sosial sebagai faktor eksternal yang memengaruhi perilaku moral. Hal ini mengacu pada berbagai argumen teoretis maupun hasil-hasil penelitian terdahulu yang telah membuktikan bahwa faktor-faktor tersebut berpengaruh terhadap perilaku moral seseorang dan dianggap relevan dengan moral remaja. Meskipun sudah terdapat penelitian-penelitian terdahulu terkait empati dan social capital dalam penelitian moral, secara khusus, penelitian ini dilakukan di sekolah Mahanaim, yang mendidik siswa-siswinya dengan menekankan kepedulian terhadap sesama dengan melakukan kegiatan-kegiatan sosial guna menumbuhkan rasa empati terhadap sesama. Kegiatan-kegiatan tersebut adalah seperti kunjungan ke tempat pembuangan sampah, melayani rumah singgah dan panti asuhan, membantu korban banjir, dan beasiswa bagi siswa tidak mampu. Selain itu maraknya penggunaan situs jejaring sosial pada remaja masa kini yang turut memengaruhi perilaku remaja baik di dunia maya maupun di dunia nyata mendorong peneliti untuk menyorotinya secara khusus dalam penelitian ini.

Hal ini diperkuat oleh penelitian Gerdes dan Segal (2011) yang menunjukkan bahwa empati adalah alat penting untuk intervensi terapeutik yang positif. Klien mengalami empati melalui cara-cara yang diajarkan dengan melakukan kebaikan kepada orang lain, menolong orang lain, dan memberi sesuatu sebagai tanda kasih yang dapat menghambat perilaku antisosial pada anak-anak dan remaja. Empati menghambat agresi terhadap orang lain dan mendorong pengembangan pribadi yang sehat. Kurangnya empati berkorelasi dengan perilaku agresif, kejahatan, kekerasan, dan masalah seksual. Dengan demikian, hasil penelitian Gerdes dan Segal (2011) menguatkan kesimpulan bahwa empati berkaitan dengan perilaku moral. Hasil penelitian lainnya juga dikemukakan oleh Miller dan Wallis (2011) mengenai interaksi sosial dan peran empati dalam manajemen informasi dan pengetahuan. Penelitiannya menyatakan bahwa empati berperan dengan adanya interaksi sosial untuk meningkatkan informasi dan pengetahuan. Dengan kata lain, seseorang akan lebih mampu menunjukkan rasa empati bila ada orang-orang yang saling berinteraksi, menunjukkan kepedulian untuk saling bertukar informasi dan pengetahuan. Kemudian, penelitian Ma, Li, dan Pow (2011) menyebutkan bahwa secara umum remaja yang berperilaku prososial cenderung lebih prososial dalam penggunaan internet, demikian pula remaja yang berperilaku antisosial cenderung lebih antisosial dalam penggunaan internet. Dengan kata lain, terdapat hubungan positif antara perilaku remaja 
di dunia maya dan dunia nyata berkaitan dengan penggunaan situs jejaring sosial. Hal ini mengindikasikan bahwa remaja kini menjadikan situs jejaring sosial sebagai bagian dari kehidupan sosialnya yang dalam kehidupan nyata banyak memengaruhi perilakunya.

Merujuk pada pemaparan mengenai permasalahan perilaku moral pada remaja yang dilandasi oleh berbagai argumen teoretis maupun hasil-hasil penelitian terkait, maka semua hal tersebut melatarbelakangi peneliti untuk mengangkat suatu penelitian mengenai perilaku moral pada remaja yang secara khusus disoroti oleh faktor empati dan penggunaan situs jejaring sosial. Tujuan penelitian ini adalah untuk mengetahui seberapa pengaruh empati dan penggunaan situs jejaring sosial dalam membentuk perilaku moral remaja.

Berdasarkan tujuan penelitian tersebut, maka pertanyaan penelitian dapat dirumuskan sebagai berikut: (1) Apakah ada pengaruh langsung dan signifikan antara empati terhadap perilaku moral remaja?; dan (2) Apakah ada pengaruh langsung dan signifikan antara penggunaan situs jejaring sosial terhadap perilaku remaja?

\section{Pengaruh Empati terhadap Perilaku Moral}

Indikator-indikator empati meliputi perspective taking dan emotional concern yang masing-masing mewakili komponen kognitif dan afektif (Davis, 1983). Seseorang yang dapat menghilangkan untuk sementara pandangannya sendiri dan mengambil sudut pandang orang lain (perspective taking) akan mampu bersikap lebih toleran terhadap suatu peristiwa yang dialami orang lain dan mampu menunjukkan perasaan serta kepeduliannya (emotional concern) atas suatu permasalahan yang terjadi pada orang lain. Para psikolog yang mempelajari perilaku moral telah menyoroti pentingnya pencitraan diri sendiri dalam mengambil perspektif orang lain yang disebut empati (Detert, Sweitzer, \& Trevino, 2008).

Kedua komponen empati ini akan menghasilkan perilaku yang membawa kebaikan (perilaku prososial) bagi orang lain serta mampu menyesuaikan diri terhadap nilai dan norma yang berlaku (perilaku fleksibel), misalnya menyatakan empati dengan memberi perhatian atau menunjukkan kepedulian bagi orang lain yang mengalami kemalangan, menolong orang lain yang membutuhkan bantuan, mendengarkan keluh kesah orang lain dengan penuh ketulusan, ikut merasakan kesedihan orang lain, dan juga mampu menyesuaikan diri dengan kondisi yang dialami orang lain. Santrock (2003) mengungkapkan bahwa empati merupakan reaksi emosional seseorang terhadap orang lain yang mengalami suatu kondisi yang tidak menguntungkan. Selain itu, pengaruh empati terhadap perilaku moral juga diperkuat oleh penelitian Cotton (2012) yang menyatakan bahwa dengan membangun empati sejak anak-anak dan remaja, maka dapat mendidik moral anak-anak dan remaja. Selanjutnya, 
penelitian yang dilakukan oleh Šarić (1997) menunjukkan bahwa adanya peran empati dan penalaran moral yang dapat menghasilkan perilaku prososial pada remaja.

\section{Pengaruh Penggunaan Situs Jejaring Sosial terhadap Perilaku Moral}

Penggunaan situs jejaring sosial meliputi facebook dan twitter yang merupakan dua situs jejaring sosial dengan pengguna terbanyak khususnya remaja. Kedua situs ini bila dimanfaatkan secara positif maka dapat digunakan untuk membantu orang lain, memperluas jaringan relasi, dan sarana untuk saling bertukar informasi yang sangat bermanfaat (perilaku prososial). Selain itu, hal ini juga memungkinkan para penggunanya untuk dapat menyesuaikan diri (perilaku fleksibel) dengan para pengguna facebook dan twitter lainnya, sehingga dapat memunculkan hal-hal positif melalui dunia maya yang dapat berdampak dalam dunia nyata.

Penelitian Wijaya dan Godwin (2012) menemukan bahwa aktivitas jejaring sosial (facebook dan twitter) memberikan pengaruh dalam kehidupan dunia nyata pada remaja, baik secara prososial maupun antisosial. Secara prososial, remaja menggunakan situs jejaring sosial sebagai media pertemanan, bertukar informasi, memperluas wawasan, bahkan bisnis online yang dapat memberikan keuntungan secara materi; sedangkan secara antisosial, tidak jarang ditemukan adanya pertengkaran yang terjadi di situs jejaring sosial, menyebarkan foto-foto atau tautan yang tidak pantas, status-status yang tidak membangun, dan lain sebagainya. Ketika seseorang terpapar dengan media digital dan internet dalam kurun waktu yang lama, hal tersebut akan mengembangkan cara baru untuk bersosialisasi, berinteraksi, berpikir, dan berperilaku (Tapscott, 2009). Hasil penelitian Sponcil dan Gitimu (2012) menemukan bahwa para mahasiswa setidaknya memiliki satu jenis situs jejaring sosial sebagai sarana untuk membangun komunikasi dan bergaul dengan orang lain yang kurang lebih berpengaruh dalam kehidupannya sehari-hari. Dari uraian di atas, dapat dikatakan bahwa situs jejaring sosial, khususnya facebook dan twitter yang saat ini kian merebak di kalangan remaja, dapat memengaruhi perilakunya dalam kehidupan nyata.

\section{METODE}

\section{Partisipan}

Teknik sampling yang digunakan adalah sampel jenuh atau sensus yaitu semua unit subjek dijadikan sampel penelitian, dengan total responden 294 orang mencakup 124 laki-laki dan 170 perempuan dari kelas X dan XI sebuah sekolah di Bekasi. Dalam penelitian ini tidak melibatkan kelas 
XII dikarenakan sudah berada di akhir masa sekolahnya. Pengambilan data responden SMA/SMK dilakukan setelah pelaksanaan Ujian Nasional dan Ujian Akhir Sekolah sehingga tidak melibatkan kelas XII. Pengambilan data pada waktu tersebut dilakukan agar tidak mengganggu konsentrasi responden yang sebelumnya sedang fokus mempersiapkan diri mengikuti serangkaian Ujian Akhir. Selain itu jumlah total responden SMA/SMK kelas X dan XI telah mencukupi ukuran sampel yang dibutuhkan.

\section{Desain}

Penelitian ini merupakan penelitian kuantitatif. Ditambahkan lagi, penelitian ini ingin melihat pengaruh langsung serta signifikansinya pada variabel bebas terhadap variabel terikat.

\section{Prosedur}

Siswa yang menjadi responden penelitian diberikan kuesioner penelitian yang dibuat sendiri oleh peneliti, terdiri dari alat ukur empati yang memiliki 8 butir, alat ukur penggunaan situs jejaring sosial dengan 8 butir, dan alat ukur perilaku moral dengan 8 butir.

Alat ukur empati menggunakan model skala Likert berdasarkan aspek kognitif dan afektif empati yang diutarakan oleh Davis (1983), meliputi perspective taking dan emotional concern. Skala ini memiliki dua bentuk pernyataan yaitu favorable dan unfavorable. Terdapat lima alternatif pilihan jawaban dari model skala Likert dengan bobot skor 1-5 antara lain; sangat sesuai, sesuai, cukup sesuai, tidak sesuai, dan sangat tidak sesuai.

Untuk alat ukur penggunaan situs jejaring sosial dan perilaku moral, digunakan skala semantic differential yang memiliki dua bentuk pernyataan kata yang saling berlawanan dengan bobot skor 1-7. Alat ukur penggunaan situs jejaring sosial disusun berdasarkan macam-macam situs jejaring sosial dengan jumlah pengguna terbanyak di Indonesia, yaitu facebook dan twitter dan alat ukur perilaku moral disusun berdasarkan jenis-jenis perilaku moral yang diutarakan oleh Megan (2009) dan Engin (2004), meliputi indikator perilaku prososial dan perilaku fleksibel. Menurut Hair, Black, Babin, dan Anderson (2010), penggunaan variasi model skala diperlukan agar dapat menghindari constant methods bias yaitu adanya kesamaan dalam mengukur suatu variabel dikarenakan metode pengumpulan data seperti kesamaan model skala untuk semua variabelnya.

Uji coba instrumen dilakukan teknik statistik 1st Order CFA (Confirmatory Factor Analysis) yang perhitungannya dengan program Lisrel 8.80. Teknik statistik CFA dilakukan guna memodelkan hubungan antara variabel laten dengan variabel-variabel teramati yang bersifat congeneric, yaitu satu variabel teramati hanya mengukur sebuah variabel laten (Wijanto, 2008). Istilah lain yang dikemukakan 
oleh Hair, dkk. (2010) mengenai hal ini ialah discriminant validity, guna memastikan bahwa sebuah konstruk berbeda dengan konstruk lainnya dalam suatu model.

Dari hasil uji coba seluruh instrumen penelitian dengan 1st Order CFA, ditetapkan bahwa butirbutir valid adalah butir-butir dengan nilai muatan faktor $\geq .5$ dan nilai error-nya $<.7$ (Hair, dkk., 2010). Begitupun dengan construct reliability (CR) dan variance extracted (VE) yakni CR $\geq .7$ dan VE $\geq .5$ (Wijanto, 2008) yang perhitungannya dilakukan dengan rumus (1) CR dan (2) VE:

$$
\begin{aligned}
& \mathrm{CR}=\frac{\left(\sum \mathrm{SLF}\right)^{2}}{\left(\sum \mathrm{SLF}\right)^{2}+\left(\sum \mathrm{e}\right)} \\
& \mathrm{VE}=\frac{\sum \mathrm{SLF}^{2}}{\sum \mathrm{SLF}^{2}+\left(\sum \mathrm{e}\right)}
\end{aligned}
$$

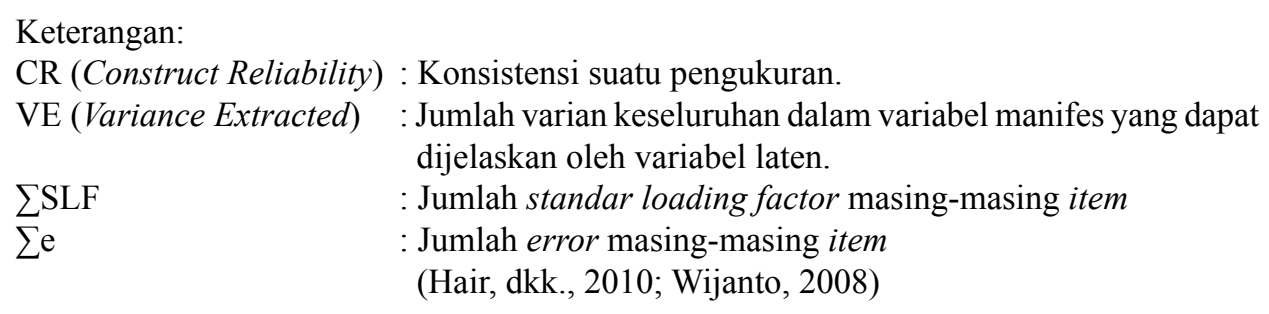

Berdasarkan hal tersebut, hasilnya tertera di bawah ini, antara lain:

Tabel 1.

Hasil Uji Coba Skala Perilaku Moral

\begin{tabular}{cccccccc}
\hline No & Indikator & $\begin{array}{c}\text { Jumlah item } \\
\text { sebelum uji } \\
\text { coba }\end{array}$ & $\begin{array}{c}\text { Jumlah } \\
\text { item setelah } \\
\text { uji coba }\end{array}$ & $\begin{array}{c}\text { No item } \\
\text { valid }\end{array}$ & $\begin{array}{c}\text { No item } \\
\text { gugur }\end{array}$ & $\begin{array}{c}\text { Muatan } \\
\text { Faktor }\end{array}$ & Error \\
\hline 1 & Perilaku Prososial & 4 & 2 & 1,4 & 2,3 & $.62 ; .71$ & $.46 ; .38$ \\
2 & Perilaku Fleksibel & 4 & 3 & $5,6,8$ & 7 & $.64 ; .74 ; .56$ & $.43 ; .3 ; .59$ \\
\hline Total item & $\mathbf{8}$ & $\mathbf{5}$ & & & & \\
\hline
\end{tabular}

Construct Reliability (CR): .83; Variance Extracted (VE): .50

Tabel 2.

Hasil Uji Coba Skala Empati

\begin{tabular}{cccccccc}
\hline No & Indikator & $\begin{array}{c}\text { Jumlah item } \\
\text { sebelum uji } \\
\text { coba }\end{array}$ & $\begin{array}{c}\text { Jumlah } \\
\text { item setelah } \\
\text { uji coba }\end{array}$ & $\begin{array}{c}\text { No item } \\
\text { valid }\end{array}$ & $\begin{array}{c}\text { No item } \\
\text { gugur }\end{array}$ & $\begin{array}{c}\text { Muatan } \\
\text { Faktor }\end{array}$ & Error \\
\hline 1 & $\begin{array}{c}\text { Perspective Taking } \\
\text { Emotional Concern }\end{array}$ & 4 & 3 & $1,3,7$ & 5 & $.70 ; .65 ; .72$ & $.38 ; .44 ; .34$ \\
2 & 4 & 2 & 4,8 & 2,6 & $.58 ; .68$ & $.60 ; .41$ \\
\hline Total item & $\mathbf{8}$ & $\mathbf{5}$ & & & & \\
\hline
\end{tabular}

Construct Reliability (CR): .84; Variance Extracted (VE): .51 
Tabel 3.

Hasil Uji Coba Skala Situs Jejaring Sosial

\begin{tabular}{llcccccc}
\hline No & Indikator & $\begin{array}{c}\text { Jumlah item } \\
\text { sebelum uji } \\
\text { coba }\end{array}$ & $\begin{array}{c}\text { Jumlah } \\
\text { item setelah } \\
\text { uji coba }\end{array}$ & $\begin{array}{c}\text { No item } \\
\text { valid }\end{array}$ & $\begin{array}{c}\text { No item } \\
\text { gugur }\end{array}$ & $\begin{array}{c}\text { Muatan } \\
\text { Faktor }\end{array}$ & Error \\
\hline $1 \quad$ Facebook & 4 & 3 & $1,2,3$ & 4 & $.65 ; .79 ; .63$ & $.51 ; .37 ; .53$ \\
$2 \quad$ Twitter & 4 & 2 & 6,7 & 5,8 & $.64 ; .79$ & $.52 ; .37$ \\
\hline \multicolumn{1}{l}{ Total item } & $\mathbf{8}$ & $\mathbf{5}$ & & & & \\
\hline
\end{tabular}

Construct Reliability (CR): .84; Variance Extracted (VE): .52

\section{Teknik Analisis}

Metode analisis data dalam penelitian ini adalah teknik analisis model struktural. Analisis data dengan menggunakan SEM (Structural Equation Model) yang pengolahannya dilakukan dengan menggunakan program Lisrel (Linear Structural Relationship) 8.80, yang bermaksud menguji hipotesis hubungan struktural dalam model teoretik apakah fit (cocok) dengan data empirik.

\section{ANALISIS DAN HASIL}

Partisipan dalam penelitian ini adalah siswa-siswi SMK/SMA kelas X-XI. Berikut gambaran data demografinya:

Tabel 4.

Data Responden SMK/SMA

\begin{tabular}{cccccccccc}
\hline & & \multirow{2}{*}{$\begin{array}{c}\text { Siswa yang } \\
\text { mengikuti }\end{array}$} & Lk & Pr & & \multicolumn{3}{c}{ Jurusan } \\
penelitian & Kelas & & & & Ani & Mar & IPA & IPS \\
\hline \multirow{2}{*}{ SMK } & $\mathrm{X}$ & 52 & 24 & 28 & 20 & 32 & & \\
& $\mathrm{XI}$ & 30 & 12 & 18 & & 30 & & \\
SMA & $\mathrm{X}$ & 95 & 41 & 54 & & & & \\
& $\mathrm{XI}$ & 103 & 40 & 63 & & & 41 & 62 \\
\hline Total & & 280 & 117 & 163 & 20 & 62 & 41 & 62 \\
\hline
\end{tabular}

Keterangan: Lk (Laki-laki); Pr (Perempuan); Ani (Animasi); Mar (Marketing)

Berdasarkan tabel di atas, terlihat bahwa total responden dalam penelitian ini sebanyak 280 orang, dengan jumlah responden SMK dari kelas X - XI sebanyak 82 orang dan responden SMA dari 
kelas X - XI sebanyak 198 orang. Dari segi jenis kelamin, terlihat bahwa jumlah responden perempuan lebih banyak daripada responden laki-laki yakni sebanyak 163 orang sedangkan jumlah responden laki-laki sebanyak 117 orang.

Berdasarkan bidang-bidang jurusan responden penelitian baik SMK maupun SMA, diperoleh data bahwa jumlah responden SMK jurusan marketing lebih banyak dari jurusan animasi, yaitu sebanyak 62 orang, sedangkan jurusan animasi sebanyak 20 orang. Hal ini dikarenakan pada saat pengambilan data kelas XI dengan jurusan animasi sedang melakukan Praktik Kerja Lapangan (PKL) ke beberapa perusahaan. Selanjutnya, jumlah responden SMA jurusan IPS (62 orang) lebih banyak dari jurusan IPA (41 orang).

Tabel 5.

Gambaran Data Responden yang Tidak Lengkap

\begin{tabular}{|c|c|c|c|c|c|c|}
\hline \multirow{2}{*}{ Tidak Melengkapi Data } & \multirow{2}{*}{ Jumlah } & \multicolumn{3}{|c|}{ Usia } & \multirow{2}{*}{$\begin{array}{c}\text { Ket. } \\
\text { Yatim/Piatu }\end{array}$} & \multirow{2}{*}{$\begin{array}{c}\text { Tempat Tinggal } \\
\text { (Panti) }\end{array}$} \\
\hline & & 15 & 16 & 17 & & \\
\hline Responden SMK & 3 & & 2 & 1 & & \\
\hline Responden SMA & 11 & 3 & 7 & 1 & 1 & 1 \\
\hline Total & 14 & 3 & 9 & 2 & 1 & 1 \\
\hline
\end{tabular}

Berdasarkan data di atas, terlihat bahwa terdapat 14 responden tidak melengkapi data demografi yang dibutuhkan. Jumlah ini bila ditambah jumlah responden lainnya yang telah melengkapi data sebanyak 280 responden, maka total responden keseluruhan berjumlah 294 orang.

Berdasarkan hasil uji model fit terhadap model teoretik menunjukkan bahwa model memiliki indeks fit $\chi^{2}=678.17, d f=227$ dengan $p=.00, R M S E A=.07, N F I=.98 ; C F I=.96 ; G F I=.97 ; A G F I$ $=.95$, maka uji hipotesis antar variabel dapat dilakukan yang uraiannya adalah sebagai berikut.

\section{Pengujian Hipotesis Satu}

Empati berpengaruh secara langsung, positif, dan signifikan $(r=.56 ; t=4.57>1.96)$ terhadap perilaku moral. Dari hasil tersebut, diketahui bahwa empati berpengaruh secara langsung, positif, dan signifikan terhadap perilaku moral.

\section{Pengujian Hipotesis Dua}

Penggunaan situs jejaring sosial berpengaruh secara langsung, positif, dan signifikan $(r=.32$; $t=2.78>1.96$ ) terhadap perilaku moral. Dari hasil tersebut, dapat disimpulkan bahwa situs jejaring sosial berpengaruh secara langsung, positif dan signifikan terhadap perilaku moral. 


\section{DISKUSI}

Dari hasil penelitian, diketahui terdapat korelasi antara empati terhadap perilaku moral. Hasil ini menunjukkan bahwa remaja yang memiliki empati, baik dengan cara perspective taking dan emotional concern, cenderung menunjukkan kebaikan, baik dalam bentuk perilaku prososial maupun dalam bentuk perilaku yang dapat menyesuaikan diri terhadap lingkungan sekitarnya (perilaku fleksibel).

Santrock (2003) mengungkapkan bahwa empati berarti bereaksi terhadap perasaan orang lain dengan respons emosional yang sama dengan orang tersebut. Dengan kata lain, seseorang yang memiliki empati terhadap orang lain adalah seseorang yang tidak hanya mementingkan dirinya sendiri, tetapi berupaya menunjukkan kepeduliannya terhadap orang lain, khususnya yang sedang ditimpa kemalangan, kesedihan, maupun suatu permasalahan. Dalam hal ini, empati tersebut ditunjukkan dalam perilaku-perilaku yang membuatnya dapat menyesuaikan diri terhadap kondisi yang dialami orang lain, sekaligus menunjukkan kepeduliannya lewat perilaku-perilaku yang positif, seperti memberi perhatian dan bantuan. Selain itu, pengaruh empati terhadap perilaku moral juga diperkuat oleh penelitian Cotton (2012) yang menyatakan bahwa dengan membangun empati sejak anak-anak dan remaja, maka dapat mendidik moral anak-anak dan remaja. Dalam hal ini, penting untuk membangun empati sejak anakanak maupun remaja agar dapat membentuk pribadi yang memiliki toleransi terhadap orang lain, mempunyai rasa kepedulian terhadap sesama, dan melatih diri untuk saling membantu, sehingga halhal baik tersebut dapat terbawa sampai dewasa.

Selanjutnya, dari hasil penelitian, diketahui bahwa penggunaan situs jejaring sosial juga berhubungan dengan perilaku moral. Meskipun nilainya rendah, hasil ini menunjukkan signifikansi situs jejaring sosial dalam membangun relasi sosial pada kalangan remaja saat ini. Secara khusus, di Indonesia sangat jarang saat ini melihat anak remaja yang tidak memiliki situs jejaring sosial yang merupakan media yang dipakai dalam bergaul dan berperilaku. Berdasarkan penelusuran peneliti, pengguna situs jejaring sosial terbesar, khususnya facebook dan twitter, adalah remaja yang dalam penggunaannya dapat memberi dampak positif maupun negatif. Secara positif, situs jejaring sosial dapat memberi kontribusi dalam memperluas pergaulan serta memberi dan memperoleh informasi yang berguna lewat berbagai fasilitas yang tersedia, sehingga hal ini dapat dijadikan sarana untuk melakukan kebaikan (perilaku prososial) dan menyesuaikan diri dalam bergaul (perilaku fleksibel). Sedangkan secara negatif, situs jejaring sosial dapat membuat seseorang menipu orang lain, bertengkar, dan lain sebagainya. 
Oleh karena itu, remaja harus dapat membuat pilihan yang bermanfaat dalam menggunakan kemajuan teknologi internet tersebut agar dapat memberi dampak positif bagi dirinya. Dengan demikian, dalam penelitian ini situs jejaring sosial terbukti turut membentuk perilaku moral pada remaja.

\section{SIMPULAN DAN SARAN}

\section{Simpulan}

Berdasarkan hasil penelitian, dapat disimpulkan terdapat pengaruh positif dari empati dan penggunaan situs jejaring sosial terhadap perilaku moral. Hal ini berarti semakin tinggi kadar empati yang dibentuk dalam diri remaja, maka perilakunya akan semakin bermoral, bergitupun bila penggunaan situs jejaring sosialnya diarahkan untuk hal-hal yang baik maka dapat membantu remaja dalam berperilaku baik di dunia maya maupun di dunia nyata.

\section{Saran Teoretis}

Berdasarkan tinjauan teoretis maupun observasi lapangan yang juga dapat diterapkan secara teoretis dalam penelitian berikutnya, perlu dipertimbangkan variabel lain, misalnya keharmonisan keluarga yang cukup berpengaruh terhadap perkembangan remaja itu sendiri. Berdasarkan pengalaman peneliti, banyak remaja yang bercerita bahwa permasalahan yang terjadi dalam dirinya sering kali berasal dari keluarga, seperti: orangtua yang sering bertengkar, konflik dengan saudara kandung, dan permasalahan ekonomi. Selain itu juga dapat dipertimbangkan variabel lain, misalnya: konformitas teman sebaya atau konsep diri mengingat masa remaja yang penuh gejolak, yang sering kali membuat dirinya mudah terpengaruh teman baik secara positif maupun negatif dan juga masa yang membuat remaja mencari pemahaman mengenai dirinya.

Hal selanjutnya yang dapat disarankan peneliti ialah memodifikasi penelitian secara kuantitatif dan kualitatif (mix method). Hal ini disarankan mengingat permasalahan moral yang terjadi khususnya di Indonesia banyak mengalami pergeseran, dengan kata lain sesuatu yang baik ataupun buruk belum tentu berlaku untuk orang-orang tertentu selama dirinya merasa senang dengan yang dilakukannya. Sebab itu penting pula untuk mengkaji permasalahan moral dari sudut pandang kualitatif, sehingga dapat ditemukan berbagai pandangan, fakta-fakta, maupun teori-teori baru yang dapat dijadikan acuan untuk memperbaiki moral baik secara individu maupun kelompok (keluarga, masyarakat, dan bangsa). 


\section{Saran Praktis}

Bagi remaja, disarankan agar dapat terus meningkatkan rasa peduli terhadap sesama dan cermat dalam menggunakan situs jejaring sosial, sehingga tidak terpengaruh pada hal-hal yang negatif serta merugikan diri sendiri maupun orang lain. Remaja perlu mewaspadai penggunaannya mengingat situs jejaring sosial dapat berdampak positif maupun negatif.

Bagi orangtua, disarankan agar membuka wawasan terhadap kemajuan informasi dan teknologi sehingga mendapat tambahan modal dalam mendidik anak, misalnya orangtua juga perlu mengikuti seminar dan belajar mengenai situs jejaring atau media sosial, sehingga dapat memantau hal-hal yang sedang terjadi dengan anaknya melalui media sosial dan dapat membimbing anak lebih lanjut agar perilakunya lebih bermoral. Selain itu, orangtua juga perlu memberikan waktu-waktu khusus untuk menanamkan nilai-nilai hidup yang dapat dijadikan pegangan hidup dalam berperilaku, mengingat anak remaja belum memiliki pengalaman hidup yang panjang dan sedang berada dalam masa-masa mencari identitas. Bagi guru disarankan agar dalam mengajar tidak hanya menghabiskan waktu di kelas untuk menyelesaikan materi pelajaran, tetapi juga ikut membangun siswa-siswinya dalam penanaman moral baik yang berlaku di sekolah, masyarakat, maupun secara pribadi. Guru juga perlu memberi perhatian kepada siswa baik secara akademis maupun secara pribadi mengingat guru merupakan orang tua siswa di sekolah yang ikut bertanggung jawab dalam mendidik.

Bagi sekolah maupun instansi pendidikan lainnya, disarankan agar dapat membuat programprogram yang tidak hanya melatih intelektual, tetapi juga dapat melatih moral remaja misalnya kegiatan kerohanian maupun kegiatan sosial yang dapat menumbuhkan rasa empati untuk melakukan sesuatu yang berguna bagi sesama.

\section{REFERENSI}

Borba, M. (2001). Building moral intelligence. San Fransisco, CA: Jossey-Bass.

Budiningsih, A. (2008). Pembelajaran moral. Jakarta: Rineka Cipta.

Carlo, G., \& Hardy, S. A. (2005). Identity as a source of moral motivation. Human Development, 48, 232-256.

Cotton, K. (2012). Developing empathy in children and youth. School Improvement Research Series, $1,1-18$. 
Davis, M. H. (1983). Measuring individual differences in emphaty: Evidence for a multidimensional approach. Journal of Personality and Social Psychology, 44, 113-126.

Detert, J. R., Sweitzer, V. L., \& Trevino, L. K. (2008). Moral disengagement in ethical decision making: A study of antecedents and outcomes. Journal of Applied Psychology, 93, 374-391.

Engin, E. (2004). The relationship of self concept structure and behavioral flexibility: A model relating cognitive structures to behavioral patterns (Tesis tidak dipublikasikan). Department of Psychology Middle East Technical University, Turkey.

Gerdes, K. E., \& Segal, E. (2011). Importance of emphaty for social work practice: Integrating new science. Journal of Social Work, 56, 141- 148.

Gunarsa, S. (2009). Dari anak sampai usia lanjut bunga rampai psikologi perkembangan. Jakarta: BPK Gunung Mulia.

Gunarsa, Y., \& Gunarsa, S. (2012). Psikologi remaja. Jakarta: BPK Gunung Mulia.

Hair, Jr., Black, W. C., Babin, B. J., \& Anderson, R. E. (2010). Multivariate Data Analysis. New York, NY: Pearson.

Hardy, S., Walker, L., Rackham, D., \& Olsen, J. (2012). Religiosity and adolescent empathy and aggression: The Mediating Role of Moral Identity. Psychology of Religion and Spirituality, 12, $1-12$.

Hurlock, E. (1999). Psikologi Perkembangan suatu pendekatan sepanjang rentang kehidupan. Jakarta: Erlangga.

Jahja, Y. (2011). Psikologi perkembangan. Jakarta: Kencana.

Ma, H. K., Li, C. S., \& Pow, J. W. C. (2011). The relation of internet use to prosocial and antisocial behavior in Chinese adolescents. CyberPsychology, Behavior and Social Networking, 14, 23-130.

Megan, E. J. (2009). Moral emotion expectancies and moral behavior in adolescence. Theses and Dissertations (Comprehensive). Paper 937. Ditemu kembali dari http://scholars.wlu.ca/cgi/ viewcontent.cgi?article $=1936 \&$ context $=$ etd

Miller, W., \& Wallis, J. (2011). Social interaction and the role of empathy in information and knowledge management: A literature review. Journal of Education for Library and Information Science, $52,122-132$.

Santrock, J. W. (2003). Adolescence, perkembangan remaja (6th ed.; Terj.). Jakarta: Erlangga.

Santrock, J. W. (2005). Life span development. New York, NY: McGraw Hill. 
Šarić, Z. R. (1997). The role of empathy and moral reasoning in adolescents' prosocial behavior. Institute of Social Sciences Ivo Pilar, 6, 493-512.

Sarwono, S. W. (2005). Psikologi remaja. Jakarta: RajaGrafindo Persada.

Sponcil, M., \& Gitimu, P. (2012). Use of social media by college students: Relationship to communication and self-concept. Journal of Technology Research, 1, 1-13.

Tapscott, D. (2009). Grown up digital: How the net generation change your world. New York, NY: McGraw-Hill.

Undang-Undang RI No. 20. (2003). Tentang sistem pendidikan nasional. Ditemu kembali dari http:// www.inherent-dikti.net/files/sisdiknas.pdf

Vitell, S. J., Bing, M. N., Davison, H. K., Ammeter, A. P., Garner, B. L., \& Novicevic, M. M. (2009). Religiosity and moral identity: The mediating role of self control. Journal of Business Ethics, $88,601-613$.

Wijanto, H. S. (2008). Structural equation modelling dengan lisrel 8.8. Yogyakarta: Graha Ilmu.

Wijaya, C., \& Godwin, R. (2012). Hubungan perilaku sosial dalam beraktivitas di situs jejaring sosial dan dunia nyata pada remaja di Jakarta (Skripsi tidak dipublikasikan). Universtas Bina Nusantara, Indonesia.

Zubaidi, A. (2009). Kajian terhadap perkembangan moral generasi muda. Jakarta: Mitra Wacana Media. 